\title{
Summary List
}

\section{Genetics AND Genomics}

55 Producing the UK's first carcase trait Estimated Breeding Values (EBVs) using national abattoir data K Moore, F Pearston, T Pritchard, E Wall, M Coffey

56 Estimation of genetic parameters for Video Image Analysis (VIA) carcass traits J Nani, M Coffey, K Moore

$57 \quad$ Genetic parameters for conformation traits in dairy goats S Mucha, A McLaren, R Mrode, M Coffey, J Conington

58 Genetic parameters of serum $\mathrm{Ca}, \mathrm{P}, \mathrm{Mg}$ and $\mathrm{K}$ concentration in Holstein dairy cows V Tsiamadis, A Kougioumtzis, N Panousis, M Kritsepi-Konstantinou, G Banos, G E Valergakis

Genetic parameters for enteric methane from dairy cows measured using Laser Methane Detector S Smith, M Coffey, M Chagunda, S Ross, S Denholm, E Wall

60 Genetic analysis of circulating mineral concentrations in milk and serum of dairy cows S J Denholm, A A Sneddon, A Bagnall, T N McNeilly, M C Mitchell, D J Roberts, G C Russell, E Wall

Young bull genetic growth profile for carcass weight

T M Englishby, R D Evans, G Banos, M P Coffey, K L Moore, D P Berry

$62 \quad$ Variation and genetic profile of milk fatty acid indices in dairy sheep

G Banos, S Symaiou, O Tzamaloukas, D Miltiadou

63 Reading the leaves: sheep parchment as a 1,000 year genetic resource

M J Collins, S Fiddyment, C Webb, T P O'Connor, D Bradley, M Teasdale, S Doherty, A Curtis, J Vnoucek, S Hall, J Finch

64 Estimation of genomic breeding values in a multi-breed context A Brown, G Banos, M Coffey, J Woolliams, R Mrode

Genomic-based optimum contributions with antagonistic fitness and productivity traits E Sanchez-Molano, R Pong-Wong, G Banos

A robust assay for the measurement of telomere length in dairy cattle L Seeker, B Holland, A Psifidi, G Banos, D Nussey

The problem with the chi-squared test in genome-wide association studies to detect a new autosomal recessive genetic disease G E Pollott

A meta-analysis for bovine tuberculosis resistance in dairy cattle

S Tsairidou, J A Woolliams, A R Allen, R A Skuce, S H McBride, R Pong-Wong, O Matika, E K Finlay, D P Berry, D G Bradley, S W J McDowell, E J Glass, S C Bishop

\section{Big Data}

69 Genomics and metagenomics applied to animal health and food security M Watson M A V Mudaliar, F C Thomas, M McLaughlin, R Burchmore, D Wilson, P Herzyk, P D Eckersall, R N Zadoks

71 The measurement of chicken acute phase proteins using a quantitative proteomic approach E L O'Reilly, P D Eckersall, G Mazzucchelli, E De Pauw 


\section{Animal Health and Diseases I}

72 Physico-chemical study and anti-parasitic properties of aqueous Cissus ruspolii and Adenia sp extracts K Tolossa, S C Fry, S Athanasiadou, G J Loake, J G M Houdijk

Validation of acaricidal activity of medicinal plants: in vitro and in vivo studies S Athanasiadou, E Debela, A Tolera, K Tolossa, S T G Burgess, S Terry, J G M Houdijk

\section{Yellow Highlights}

74 Geographical distribution and hosts of ixodid ticks of livestock in Oman P A Bobade, S A Al-Riyami, R M Al-Busaidi, Z A Korra, Y A Al-Shehhi, H Heyne, A Latif

Clinical text mining: the cutting edge of computer science meets the coalface of small animal veterinary practice J Newman, P-J M Noble, G Nenadic, A D Radford, P H Jones

Preliminary study of prevalence of rumen fluke in Irish flocks A M Martinez-Ibeas, N Byrne, K Lawlor, M P Munita, G Mulcahy, M Sekiya

Production performance of lactating dairy cows offered two different commercial fat supplements R M Kirkland, J Flockhart

Is there a 'colour fashion' in British bred sports horses? An investigation into British equestrians preference for horse colours and perception of equine coat colour bias

A Fisker Hansen, H Randle, J Dixon

Prevalence of Fasciola hepatica in Irish sheep flocks in 2014: Preliminary results M P Munita Corbalan, N Byrne, K Lawlor, AM Martinez Ibeas, G Mulcahy, M Sekiya, R Sayers

The effect of low-level laser therapy on the linear motility of chilled boar semen H Varnes, R Cooke, T Coop

The relationship between lameness and body condtion score in dairy cattle G Isaac, R Coffin, K Hunt

\section{Practice Based Research: forstering LinKs BetWeEn Clinicians AND ACADEMics}

Prevalence and herd-level risk factors for Fasciola spp and other trematode infections in cattle in Kwara State, North-Central Nigeria N Elelu, A G Ambali, G C Coles, M C Eisler

An investigation into the proportion of Schmallenberg virus affected lambs born into flocks where Schmallenberg virus has previously been diagnosed S Young, I Nanjiani, P Williams

Prevalence of Trypanosome species in Nigerian breeds of sheep in Abeokuta and its environs using polymerase chain reaction I K Oyewusi, M I Takeet, A O Talabi, JA Oyewusi, O O Adeleye, E B Otesile

Schmallenberg virus in a sero-endemic region: surveillance using individual blood and bulk tank milk samples Á B Collins, A Hallinan, J Grant, D Barrett, M Doherty, J F Mee 


\section{Animal Health and Diseases II}

89 Cost-benefit simulation analysis of vaccination against contagious agalactia of dairy sheep in Greece G E Valergakis, S A Termatzidou, A I Gelasakis, G Arsenos

90 The consequences of protein supplementation during gestation on performance and immune parameters in mammals

A Masuda, J E Allen, J G M Houdijk, S Athanasiadou

91 Early host responses to Clostridium perfringens in two commercial breeds as measured in situ K M Russell, P Kaiser, N H Sparks, V Parreira, J F Prescott, M A Mitchell, R E Clutton, T Kanellos, S Athanasiadou

92 In vitro screening of anti-parasitic properties of four Ethiopian medicinal plant extracts K Tolossa, S C Fry, S Athanasiadou, G J Loake, J G M Houdijk

93 Intestinal adhesion and faecal shedding of enterotoxigenic Escherichia coli in experimentally challenged weaned pigs J Pollock, D L Gally, R Tiwari, M R Hutchings, J G M Houdijk

94 Bio-assay guided fractionation of crude aqueous extracts of Cissus ruspolii and Adenia sp K Tolossa, S C Fry, S Athanasiadou, G J Loake, J G M Houdijk

95 Characterisation of a novel vaccine delivery system for livestock R K McLean, A R Wood, J C Hope, G Entrican, D J Griffiths

The effect of human isolated probiotic bacteria in preventing Campylobacter jejuni colonization of poultry N Corcionivoschi, A Cean, L Stef, R Madden

\section{Red Highlights}

97 Gonadal and extra-gonadal sperm reserves of West African Dwarf rams treated with FSH/LH M A Oguike, U N Egu, J Ezea

98 Evaluation of performance and haematological parameters of West African Dwarf goats fed selected browse specie based diet

O Akinyode, O O Adeleye, O Akinfenwa, A B J Aina

99 In vitro gas production of Pennisetum purpureum varieties fertilized with animal manures S O Badaru, V O A Ojo, A O Ogunsakin, A O Ajayi, O O Adelusi, O S Onifade

100 Seasonal variations of mineral content of grasses from natural pasture in South West Nigeria O Oluwafemi Adeyemi, J Alaba Olufunmil, D Peter Aniwe, A Bolanle Temitope

101 In vitro gas production of silage made from cultivated pastureland with or without additives from Yewa area of Ogun State Nigeria

D T Olorunnisola, V O A Ojo, O A Jolaosho, J O Olanite, A O Ogunsakin, O G Ojambati, T E Otaru, A E Adesorioye

102 Effects of thyme essential oil on abundance of sheep rumen cellulolytic bacteria as determined by real-time polymerase chain reaction

H Jahani-Azizabadi, M Danesh Mesgaran, A R Vakili, K Rezayazdi

Effect of enzyme additive on in vitro gas production and dry matter degradability of a total mixed ration K O Yusuf, E A Akinyosoye, V O A Ojo, RY Aderinboye, O A Isah, C F I Onwuka

104 Effect of grasshopper meal diets on performance of broiler chickens

O Daudu, T Yusuf, T Olugbemi, O Odegbile

Evaluation of liquid co-product feeds in ruminant diets using a mechanistic whole cow simulation model:

Biopara-Milk

V Ambriz-Vilchis, R Fawcett, A Masri, N Robertson, P Holder 


\section{FEEDS}

106 Trends in efficiency of compound feed use by dairy cows in Great Britain M Wilkinson, J Allen

107 Seasonal variability in the relationship between fatty acid and chlorophyll content of perennial ryegrass (lolium perenne)

S A Morgan, S A Huws, J K S Tweed, N D Scollan

108 Evaluating the fermentable characteristics of molasses formulated feeds and liquid co-product syrups using in vitro gas production technique

V Ambriz-Vilchis, R Fawcett, A Masri, N Robertson, P Holder

109 Evaluation of fertiliser treatment and harvesting age on proximate composition of Arachis pintoi S A Adeoye, J A Olanite, V O A Ojo, O S Onifade, F O Oke, R O Folarin, A A Ogunsusi, O M Bada

$110 \quad$ Growth parameters of Arachis pintoi as affected by fertiliser treatment S A Adeoye, J A Olanite, V O A Ojo, A O Taiwo, A Adetona, S O Ogundele

111 Predicting grass digestible and metabolisable energy contents from chemical composition S Stergiadis, M Allen, X J Chen, D Wills, T Yan

112 Chemical evaluation of selected Nigerian matured forages for their use in ruminant diets O J Bolaji, A S Chaudhry, J Dolfing

113 Bioeconomic modelling of six yearling to beef finishing systems

P Crosson, P O'Kiely, E McGeough

114 Effects of storage on the nutritive quality of grass-legume mixtures in South-western Nigeria

V O A Ojo, I G Nukasi, A O Jolaosho, O M Arigbede, J O Olanite, P A Dele, S A Adeoye, O B Ogunbote, A O Ogunsakin

\section{KNOWLEDGE EXCHANGE/EducATion}

115 E-learning and assessment systems for maths and statistics B Foster, C Perfect

116 A survey of the study methods used by students of the biological sciences B T Wolf

117 The use of the 'Muddiest Point' technique as an in class evaluation method M R F Lee

118 Instant expert: development and evaluation of an intelligent, interactive 3D computer game for teaching visual lameness assessment skills through deliberate practice S D Starke, G C Miles, SB Channon, S A May

119 3D Modelling of clinical images in veterinary medicine: development of an interactive teaching and learning application

V Mauricio, J Marshall

120 The use of online learning as continuing professional development within animal welfare organisations: A case study with IFAW

L Read, J MacKay, C Milburn, F Langford

121 Farm Health Online: Bridging the gap between science and practice for farmers

C Reigate, A Bassett, S Roderick

122 The role of vet schools in promoting a universal "culture of care" for animals: implications of the World (Organisation for Animal Health) OIE Guidelines and a global survey on criteria for animal welfare education

Titus Alexander 


\section{Feeding Zoo Animals for Health, Welfare and Conservation \\ 124 The sense of feeding fibre to carnivores \\ G P J Janssens}

125 Methane production by vertebrate herbivores - a comparative perspective

K Hagen, M Kreuzer, M Clauss

126 Designing diet management software for healthy zoo animals

A L Fidgett, M E Edwards, L Peterson, M Webster

127 Elephant Milk Composition

A Silva-Fletcher

\section{Product Quality}

128 Is extracellular vesicle production in milk associated with measures of milk output and quality in dairy cows?

G E Pollott, C Lawson, R Fowkes, K Wilson

Crossbreeding low-input dairy cows in switzerland with us brown swiss: effect on summer milk fatty acid profile

S Stergiadis, A Bieber, E Fransceschin, A Isensee, MD Eyre, V Maurer, E Chatzidimitriou, G Cozzi, B Bapst, G Stewart, A Gordon, G Butler, C Leifert

130 The effects of castrating males on lamb performance and meat eating quality attributes TWJ Keady, JP Hanrahan, V Campos, P Allen, T Sweeney

131 Effect of muscle weight on crossbred lamb meat eating quality

E M Price, J A Roden, I Richardson, N Clelland, W Haresign, G E Gardner, J M Finch, N D Scollan

132 Shelf life characteristics of meat from indigenous and foreign breeds of dairy ewes in Greece

E Kasapidou, P Sitilidis, P Mitlianga, G Arsenos

133 Metal uptake and liver antioxidants as potential biomarkers of oxidative stress in Cyprinus carpio inhabiting river Indus

F Jabeen, A S Chaudhry, H Raza

\section{Precision Cattle Farming}

134 Precision calf management for optimal health and welfare B Earley

135 Automatic prediction of parturition in dairy cows using tail-mounted accelerometers C Michie, D Ross, C Davison, J Konka, C Tachtatzis, D Bell, C-A Duthie

136 A comparison of the behaviour of lame and non-lame dairy cows using novel local positioning sensors with $3 \mathrm{~d}$ accelerometers H Hodges, Z Barker, J Vasquez-Diosdado, E Codling, N Bell, D Croft, J Amory disease

J Vandermeulen, C Bahr, D Johnston, B Earley, E Tullo, I Fontana, M Guarino, D Berckmans 


\section{Reducing Livestock Greenhouse Gas Emissions}

138 The effect of dietary forage proportion on enteric methane emissions of lactating dairy cows L F Dong, T Yan, C Ferris, D McDowell

139 Effects of dietary nitrate or oil concentration on methane $\left(\mathrm{CH}_{4}\right)$ and hydrogen $\left(\mathrm{H}_{2}\right)$ emissions from beef cattle are basal diet dependant

J A Rooke, S Troy, C-A Duthie, R J Wallace, J Hyslop, D Ross, T Waterhouse, R Roehe

140 A novel method of measuring methane $\left(\mathrm{CH}_{4}\right)$ emissions from beef cattle in group housing

S M Troy, C-A Duthie, J J Hyslop, R Roehe, D W Ross, A Waterhouse, J A Rooke

141 Methane emissions from sheep receiving dietary mixtures of heather (Calluna vulgaris) and grass

R W Mayes, F J Perez-Barberia

142 Prediction of methane emissions from lowland lambs using data measured in indirect open-circuit respiration calorimeters

Y G Zhao, A Aubry, R Annett, N E O’Connell, T Yan

143 Measurement of methane emissions from lactating dairy cows fed diets differing in forage type and neutral detergent fibre concentration using spot sampling or continuous measurement

K J Hammond, D J Humphries, A K Jones, P Kirton, L A Crompton, C K Reynolds

$144 \quad$ Life Cycle Assessment of high producing dairy production systems: do functional units matter?

S A Ross, M G G Chagunda, C F E Topp, R Ennos

145 Prediction of methane emissions from lactating dairy cows fed fresh cut grass and concentrates

D Hynes, S Stergiadis, T Yan

146 Methane $\left(\mathrm{CH}_{4}\right)$ outputs from grazing lactating beef cows of contrasting breed types on different pasture types J A Rooke, C-A Duthie, J Holland, T Waterhouse

\section{BeHAViour AND WelFARE}

147 The effect of introduction of an unfamiliar individual on the social contact patterns of groups of cattle L A Smith, D L Swain, G I Innocent, M R Hutchings

$148 \quad$ Vocalisations and their relationship with enrichment and welfare indicators in juvenile domestic pigs M Friel, K Griffin, L Asher, N O'Connell, H Kunc, L Collins

149 Quantifying the response of aggressive behaviour in growing pigs to selection via skin lesion traits S Desire, S P Turner, R B D'Eath, A B Doeschl-Wilson, C R G Lewis, R Roehe

$150 \quad$ Evaluating environmental enrichment options for commercial broiler chickens

C L Bailie, N E O'Connell

$151 \quad$ Methodology and analysis of drinking behaviour traits in turkeys J Rusakovica, V D Kremer, S Avendaño, I Kyriazakis

152 The effect of routine abattoir processes on the visibility of welfare-related lesions on pig carcasses G A Carroll, L A Boyle, D Teixeira, N van Staaveren, A Hanlon, N E O'Connell

153 Using cognitive bias as an assessment of rabbit welfare: exploring the effectiveness of initial training L Brooke, C Douglas

154 The relationship between water intake and oestrus behaviour in dairy cows

G Barrenho, M G G Chagunda, M D March, D J Roberts

155 The effect of social contact on weaning distress in dairy calves

S L Bolt, N K Boyland, J M Gibbons, D P Croft 


\section{EWE Nutrition}

156 The effect of early life nutrition on future rumen function

C J Newbold, K Waddams, L Abecia, A Belanche, D R Yáñez-Ruiz

157 A determination of sample number requirements for nutritional analyses in sheep

N R Kendall, L A Stubbings, K D Sinclair

158 Effect of level and source of protein supply on the performance of ewes during late pregnancy and early lactation

R G Wilkinson, C Gauld, A M Mackenzie, S E Pattinson, J Donaldson

159 The effect of stocking rate and prolificacy potential on ewe production efficiency from pasture based production systems

E Earle, N McHugh, T M Boland, P Creighton

160 Effect of supplementary tannin on feed intake and digestibility in ewes offered lucerne silage during late pregnancy and early lactation

V Taha, R Wilkinson, D Davies, J Huntington

161 The impact of concentrate supplementation on grass dry matter intake of twin suckling ewes during early lactation and subsequent effects on lamb performance

F P Campion, F M McGovern, E Levičnik, P Creighton, T M Boland

162 By-pass based protein supplementation and periparturient ewe performance

J G M Houdijk, L A Smith, J E Vipond

163 Relationship between body condition, back-fat and muscle depth in Suffolk x Mule ewes

R G Wilkinson, C Gauld, A M Mackenzie, S E Pattinson, J Donaldson

\section{Animal Science, Politics and Policy}

164 Animal science, politics and policy - a New Zealand perspective

Rt Hon Sir Lockwood Smith

\section{Food Safety and Campylobacter}

165 Methods to control the level of Campylobacter during poultry processing

M Howell

166 Bacteriophage control of Campylobacter in broiler chickens

I Connerton, P L Connerton

\section{The Future of SuckLing Systems}

167 Technical and economical performance of grass-based suckling systems of contrasting intensities P Crosson, EJ McGeough, P O'Kiely

168 An analysis of the English beef industry over the last 10 years M Topliff

169 Suckler beef systems in France: recent evolution, challenges and future prospects C Mosnier, J Agabriel, M Lherm, P Veysset

170 US suckler system sustainability - maintaining economic viability in a changing market J L Capper 


\section{Sustainable Protein}

171 Animal Electronic Recording, Transmission and Synthesis (ALERTS); decision support technologies for the farming sector I Andonovic, C Michie, D Ross, M Mitchell, J Konka, C-A Duthie, W Thomson, A Loftus, J Hyslop, M Bateman, A Warne

172 Insects - an alternative protein source for use in monogastric livestock feed M E Wakefield, A Charlton, M Dickinson, K Robinson, E Fitches, A Booth, J Sissins, H Hall

173 Bean starch concentrates as home grown alternative to soya bean meal in grower and finisher pig diets L A Smith, M Balduino Gonçalves dos Reis, O Olukosi, J G M Houdijk

174 Relationships between dry matter intake and animal metabolic liveweight in young Stabiliser breeding bulls and finishing Stabiliser steers J J Hyslop, R Fuller, U Taylor, D Thirlwell, D Dreux

175 Genetic determination of net feed efficiency (NFE) and other performance traits in Stabiliser beef cattle R Roehe, R J Fuller, U Taylor, D Thirlwell, D Dreux, J J Hyslop

176 Animal performance and efficiency of two divergent breeds of finishing steers offered either a concentrate-straw or a silage based diet ad libitum with either nitrate or increased dietary oil C-A Duthie, J Rooke, S Troy, J J Hyslop, D Ross, A Waterhouse, R Roehe

\section{Cattle Health and Disease}

177 The impact of a health intervention scheme on the mobility of dairy cattle in the South West of England F Shepherd, H Randle, P Ward

178 Prevalence of subclinical hypocalcaemia in Holstein dairy cows V Tsiamadis, N Panousis, M Kritsepi-Konstantinou, A Kougioumtzis, G Banos, G E Valergakis

179 Development of a model to investigate the host-parasite interactions between first season grazing calves and O. ostertagi

Z Berk, S Bishop, A Forbes, I Kyriazakis

180 Evaluation of a model to investigate the host-parasite interactions between first season grazing calves and O. ostertagi

Z Berk, S Bishop, A Forbes, I Kyriazakis

181 Low periconception and first trimester dietary protein affects development of immune function in beef calves D Lomas, K Copping, R Flynn, T Coffey, V E A Perry

182 The prevalence and direct financial implications of pneumonia in slaughtered cattle in Kumasi abattoir, Ghana

V Attoh-Kotoku, B Emikpe, E L K Osafo, A Donkoh, O D Tawiah

183 Identification of the rumen fluke Calicophoron daubneyi infecting cattle in Wales K M Huson, P M Brophy, R M Morphew, N D MacKintosh

184 A comparison of mastitis incidence in conventionally managed and organic dairy cows on the same farm R Houghton, C Douglas, F da Mata

\section{Dairy - Feed and Nutrition}

185 Effect of concentrate feed rate within a feed-to-yield system on the performance of dairy cows in early to mid-lactation

P J Purcell, R A Law, C P Ferris

186 The effects of out-wintering replacement dairy heifers on deferred grazing, kale or fodder beet without or with a trace mineral bolus on pre-calving performance in commercial spring calving herds

N E Atkins, E C L Bleach, P R Hargreaves, L A Sinclair 

with a trace mineral bolus on first lactation performance in commercial spring calving herds N E Atkins, E C L Bleach, P R Hargreaves, L A Sinclair

The effects of temperature and humidity on feeding behaviour depends on genetic merit in a temperate herd of dairy cows

D L Hill, E Wall

Replacement of grass and maize silage with lucerne in the diet of high yielding dairy cows: effects on performance and milk fatty acid profile

L A Sinclair, R Edwards, K A Errington, A M Holdcroft, M Wright

The effect of supplementation with a rumen-protected fat (Megalac $®)$ through an extended period of lactation on milk production of dairy cows in a pasture-based dairy system in Tasmania

M J Freeman, R M Kirkland

191 The effect of supplementation with a rumen-protected fat (Megalac $®$ ) on fertility and blood metabolite concentration of lactating dairy cows in a pasture-based dairy system in Tasmania M J Freeman, R M Kirkland

192 Effect of concentrate allocation strategy on the performance of dairy cows in early to mid -lactation P J Purcell, R A Law, C P Ferris

Analysis of heat stress in Greek dairy cattle and impact on milk yield and milk quality M-A Karatzia, E Sossidou

194 Effect of dry cow diet on colostrum IgG concentration and volume of colostrum fed on immune status in Holstein dairy calves

A Dunn, S Morrison, M Welsh, A Ashfield, A Gordon, B Earley

\section{Dairy Production}

195 Impact of routine hormone treatments for the reproductive management of dairy herds on reproductive efficiency and methane emissions: A stochastic simulation study

S C Archer, C D Hudson, M J Green

196 Effect of pre-implantation factor in an in vitro model of bovine E. coli endometritis R E Clamp, M Natoli, E R Barnea, D Nash, M T Rose

The relationship between fatty acid profiles in milk identified by fourier transform infrared spectroscopy and onset of luteal activity in Norwegian dairy cows

A D Martin, N K Afseth, A Kohler, Å Randby, M Ekænes, A Waldmann, O Reksen

198 Culling in the dairy herd: have cows paid back their cost of rearing?

A C Boulton, J Rushton, D C Wathes

199 Current rearing practices for pre-weaned dairy heifer calves in Britain: is there room for improvement? A C Boulton, J Rushton, D C Wathes

200 Effect of plane of nutrition on growth rate, feeding behaviour and systemic metabolite concentrations in pre-weaned bull calves of two contrasting dairy breeds C Byrne, A M English, D A Johnston, S Fair, P Lonergan, D A Kenny

\section{RUMEN FERMENTATION IN VITRO}

201 Use of NIRS to describe the time course of rumen fermentation of herbage

J M Bowen, R J Dewhurst, S J Lister 
Effects of ten whole essential oils on rumen fermentation and biohydrogenation of $n-3$ polyunsaturated fatty acids by rumen microorganisms in vitro

P O Eburu, S Chikunya

204 The effects of graded doses of 4-allylanisole, anethole, anise oil and cassia oil on fermentation and biohydrogenation of $n-3$ polyunsaturated fatty acids by rumen microorganisms in vitro

P O Eburu, S Chikunya

205 In vitro screening of different biochars as antimethanogenic feed additives for ruminants

I Cabeza, R Dewhurst, T Waterhouse, S Sohi, J Rooke

206 In vitro as production and methane reduction in Panicum maximum incubated with palm kernel oil O O Adelusi, C F I Onwuka, O J Idowu, R Y Aderinboye, V O A Ojo

207 In vitro gas production of leaf and stem fractions of Pennisetum purpureum varieties fertilized with animal manures

O O Oduyemi, V O A Ojo, A O Ogunsakin, O O Adelusi, O A Okukenu, Y T Adesetan, S T Adewuyi, E D Oyebanjo

208 Effects of supplementing cassava peels with cassava leaves and cowpea haulms on rumen environment parameters of West African dwarf goats

A O Oni, O M Abatan, K Adebayo, S O Iposu, O S Sowande, C F I Onwuka, O O Oni

\section{Poultry/Exotics}

209 Comparative study between the impact of L-ascorbic acid and $a$-tocopherol acetate on immune response, performance and egg composition of Egyptian native Fayoumi hens

M M Zaki, Maha M Hady

210 Physicochemical assessment of Quail nuggets as affected by Ocimum gratissimum extract O O Olusola, D O Oshibanjo, L A Abegunde, J Aremu, O O Oyadeyi

211 Utilisation of heat treated jatropha seed cake in the diets of growing Japanese quails A F Agboola, A A Adenuga

212 Evaluation of the effects of cloves (Syzygium aromaticum), tumeric (Curcuma longa) and African nutmeg (Monodora myristica) on the performance of Japanese quails (Coturnix cortunix japonica)

T S Olugbemi, I I Adedibu, K E Idowu

213 Metabolisable energy of oilseed rape meal is dependent on its gross energy and protein content O A Olukosi, M Kasprzak, S Kightley, J Wiseman, P Carre, J G M Houdijk

214 Sexual dimorphism in haematological traits of Japanese quails (Coturnix cortunix japonica) fed Moringa Oleifera seed meal

I I Adedibu, Z Aliyu, O M Akinsola, O M Daudu, T S Olugbemi

215 Production of omega-3 fatty acids-enriched table eggs

H Al-Khalaifah, A Al-Nasser, M Al-Bahou, F Khalil, G Ragheb, M Boarki

216 Effect of length and storage methods on the chemical composition of exotic chicken and quail eggs I Dudusola

\section{Poultry/Broilers}

217 Replacement value of African pear (Dacryodes edulis) seed meal as a protein source in broiler diets O O K Oko, A A Ayuk, O M Emeruwa, F E Elijah, E E Ekpe, B O Asuquo, B I Okon, L N Agwunobi

218 Evaluation of dietary Moringa oleifera leaves incorporation on performance parameters and anticoccidial activity in broiler chickens

Maha M Hady, Mohamed M Zaki 
Comparison of performance data and feed efficiency measurements from broiler chickens raised in a similar manner but in two different countries

F Mansoor, B Zebeli, C Donaldson, P Lawlor, R Hawken, E Magowan

Lime (Citrus aurantifolia) juice as a source of natural organic acids can improve the growth of broiler chickens

E Ndelekwute, G Enyenihi, E Assam, U Ufot, O Otu

\section{Multiple Species}

221 Pelage colour as a non-invasive measure of blood plasma melatonin in the red deer (Cervus Elaphus)

D J G Charman, A H Stewart, A M Mackenzie

222 Assessing the impact of environmental tobacco smoke on the biological age of pet dogs

N C Hutchinson, C M Knottenbelt, L Nasir, D J Mellor

223 Bodyweight, feed intake and activity rhythms of entire and neutered female cats during the transition from autumn to winter

D G Thomas, J Cormier

224 Performance of growing rabbits fed graded inclusion levels of sun-dried shrimp waste meal based diets A Okorodudu, O O Oduguwa, A O Fafiolu, A O Ogunsakin

225 Reproductive potential of rabbit bucks orally administered exogenous organic selenium E O Ewuola, D E Akinyemi

226 The choice of diet affects the oral health of the domestic cat F Mata

\section{Blue Highlights}

227 Hip scoring for canine hip dysplasia: A comparison of British and German breeding strategies C Douglas, F Mata, G Menem

228 Effect of two dietary schemes in the pre- and early post-weaning phase on within-batch heterogeneity at 10 weeks of age

S P Paredes, T de Waele, J W Resink

229 Feeding values of Pennisetum purpureum varieties fertilized with animal manures O G Ojambati, V O A Ojo, S A Adeoye, T K Adeleye, T B Oyekunle, O M Arigbede, E O Ojo, S O Badaru

230 Effect of supplementation of forages of cassava, Gliricidia and Leucaena on the growth and faecal egg count of semi intensively managed sheep
O A Fasae, J E O Omosun

231 Effects of a blend of essential oils on rumen microbial fermentation of a 50:50 lucerne: concentrate diet in dual-flow continuous culture system

N Khosrozad, O Azizi, H Jahani-Azizabadi

232 Prophylactic liniment mint oil cream treatment reduces cows' somatic cell counts in on-farm trials K Zaralis, W Waterfield, S Padel

233 No effect of gonadotropin releasing hormone agonist on the cardiac function of young sheep I Sanz, A Corda, E Barzack, O Marron, C Watson, C Wyse, D Hough, M Bellingham, M McLaughlin, A French, N Evans

\section{Pig Production/Performance}

234 The effects of dietary digestible phosphorous, phytase and zinc oxide on the growth performance of weaner pigs

S C Mansbridge, A M Mackenzie, V Pirgozliev, C L Walk, M R Bedford, I Wellock, A H Stewart 

residual feed intake reared at different sites across Europe

S Buzoianu, U McCormack, D Berry, G Gardiner, E Magowan, F Mansoor, B Metzler-Zebeli, P Varley, P Lawlor

236 Effect of creep feeding and use of a sweet gel post weaning on weaner pig performance F Mansoor, E Magowan

237 The potential of co-products to reduce the environmental impact of pig systems S G Mackenzie, N Ferguson, I Leinonen, I Kyriazakis

238 The variation in finishing pig feed conversion efficiency between and within herds E Magowan, V Beattie, S Smyth, K McCracken, G Donaldson, F Gordon, M Hawe

239 Pig and carcass performance when feed is offered in dry or liquid form E Magowan, V Beattie

240 The effect of phytase on grower pig growth performance and bone ash S Laird, I Kühn, P Wilcock, H M Miller

241 Does grouping pigs according to sex at weaning improve early post-weaning performance? A E Taylor, H M Miller

\section{Pigs/Sows}

$242 \quad$ Factors affecting sow udder morphology

A Balzani, E Sutcliffe, H J Cordell, S A Edwards

243 Effects of short-term (7 day) treatment with growth promoters on livers of growing gilts S Al-Doski, D Brown, M Mareko, K Ryan, J Brameld, T Parr

244 Review of scientifc knowledge on lactation nutrition of highly prolific modern sows A Craig, E Magowan, A Gordon

245 Measuring metabolic hormones in pig blood using a human bead-based multiplex assay K May, J M Brameld, H V Masey O'Neill, J Wiseman, T Parr, S E O'Sullivan

246 The use of whey permeate in the lactation diet on sow feed intake and litter performance P McMullen, W Henry, A O'Connell, R Wregor, E Magowan

247 Teat accessibility in relation to sow udder morphology

A Balzani, H J Cordell, S A Edwards

\section{Microbiotic ANd Gut Mucosa}

248 Factors associated with the development of caecal dysfunction in growing turkey poults C Rymer, D T Juniper, S Brand, K Maxam, A Tonks, R Ahmed, F Alkandari, S Indrakumar, C Poulos, M Woodward

249 The role of attapulgite in the colonization of potential pathogens in laying hens' caecum S Chalvatzi, E Petridou, G Filiousis, T Poutahidis, G Papadopoulos, G Arsenos, P Fortomaris

250 The use of bacterial 16S rDNA restriction fragment length polymorphisms (RFLP) to monitor diet induced changes in rumen bacterial populations of cattle in an in vitro model of rumen fermentation $\mathrm{K}$ McDermott

251 Effects of probiotics on the intestinal microflora of finishing broiler chickens O O Oni, O M O Idowu, A O Oni, A O Oso, C O N Ikeobi 
253 Influence of L-dopa of Mucuna pruriens on growth response and gut mucosa integrity of broiler chickens B R O Omidiwura, A F Agboola, M K Adeoye, E A Iyayi

254 Effect of combination of turmeric, ginger and garlic extracts on performance, microbial load and gut morphology of weaned pigs

A Adebukola Olufemi, Nsisongabasi P Jimmy, O Taiwo Olakunle, M Bosede Adetutu

\section{Animal Health and Greenhouse Gas Emissions}

255 The global livestock sector: Trends, drivers and implications for society, health and the environment T P Robinson, G R W Wint, G Conchedda, G Cinardi, T Van Boeckel, B Bett, D Grace, M Gilbert

256 Modelling the impact of controlling UK endemic cattle diseases on greenhouse gas emissions J Elliott, G D Jones, A Williams, J Chatterton, B Drake, Z Wu, G Hateley, A Curwen

257 Benefits of improving cattle health on greenhouse gas emissions (GHGE) in the UK A G Williams, J C Chatterton, G Hateley, A Curwen, J Elliot

258 Periparturient parasitism increases ewe methane production per kilogram lamb weaned J G M Houdijk, B J Tolkamp, J A Rooke, M R Hutchings

New emerging infectious diseases in livestock related to climate change W H M Van der Poel, R J Bouwstra, A R W Elbers, P T J Willemsen

Impact of early parasitic gastroenteritis and elevated environmental temperature on growth performance of lambs S Ptochos, S Athanasiadou, M Haskell, M Hutchings, J Houdijk

\section{SHEEP}

261 Effects of a two-breed and a three-breed rotational breeding strategy on ewe and lamb performance in hill flocks A Aubry, R W Annett, D Irwin, A W Gordon

Effect of a colostrum alternative and milk replacer on animal performance, health, rumen fermentation and blood metabolites in lambs

A Belanche, C L Faulkner, E Jones, H J Worgan, J Cooke, C J Newbold

263 Prediction of nitrogen excretion in lowland lambs offered fresh grass based diets Y G Zhao, A Aubry, R Annett, N E O’Connell, T Yan

264 The effects of supplementation with cobalt, alone or in combination with vitamin B12 and selenium, on postweaning performance of lambs on pasture

T W J Keady, S P Fagan, J P Hanrahan

265 Effects of growth promoters on expression of serine biosynthetic pathway genes in ovine liver and skeletal muscle

S Al-Doski, K Hemmings, Z Daniel, J Brameld, T Parr

266 Relationship between body condition score and ultrasound measurements of backfat thickness in dairy Chios ewes

S-A Termatzidou, G E Valergakis, M N Patsikas, G Bramis, G Arsenos

267 Application of a mechanistic model to analyse the environmental factors that affect lactation curves of dairy sheep

J C Angeles Hernandez, B Albarrán Portillo, A H Ramirez Perez, A C Lizarazo Chaparro,

O A Castelan Ortega, M Gonzalez Ronquillo 


\section{Advances in Equine Science}

268 A better way to feed the performance horse

M J S Moore-Colyer

269 Effect of supplementation with selenium and vitamin E on serum malondialdehyde and creatinine phosphokinase concentrations in horses under moderate exercise

E Velazquez-Canton, A H Ramiez-Perez, L A Zarco-Quintero, F Meschy, D A Castillo-Mata,

J C Angeles-Hernandez

\section{Equine Performance and Sports Medicine}

270 The equine atheletic heart

C M Marr

271 A comparison of a traditional treed saddle and a working prototype which utilises an innovative structure T E Ward

272 The effects of manual chiropractic (McTimoney) and instrument assisted chiropractic on spinal mechanical nociceptive thresholds (MNTs) in flat racehorses without clinical signs

N Rossa, S Charlton, C Cunliffe

273 The effect of manual chiropractic (McTimoney) treatment on pressure measurements beneath the saddle A Crosby-Jones, N Routledge, C Cunliffe

274 A preliminary study of the effect of manual chiropractic treatment on the splenius muscle in horses when measured by surface electromyography

J Langstone, J Ellis, C Cunliffe

\section{Advances in Equine Reproduction Research}

275 Causes of early equine pregnancy loss: are we making progress?

A M de Mestre

276 Effect of Single Layer Centrifugation (SLC) on mitochondrial membrane potential and reactive oxygen species production by stallion spermatozoa

J Morrell, A Lagerqvist, P Humblot, A Johannisson

277 The effect of a sperm washing step on flow cytometric evaluation of reactive oxygen species production by stallion spermatozoa

J M Morrell, A Georgakas, D Nash, M C G Davies Morel, A Johannisson

278 Restriction of daylength does not influence the time of the final ovulation during the autumn transition in mares

J Newcombe

Effect of mating to ovulation interval on foal gender, live foal rate and pregnancy rate in Thoroughbred horses

N Tarapor, M Davies-Morel, J Newcombe

\section{Productive Interaction between Industry and Research}

280 Education in partnership with industry: what BEF does and what we could do J Rogers, J Dixon

281 Preliminary investigation into equine coat colour bias within the British Breeding Futurity young horse evaluations

A Fisker Hansen, H Randle, J Dixon 